\title{
KEPADATAN, KEANEKARAGAMAN, DAN LINGKUNGAN TERIPANG DI GUGUSAN PULAU KELAPA, KEPULAUAN SERIBU
}

\author{
Sri Turni Hartati* ${ }^{*}$ dan Indar Sri Wahyuni ${ }^{*}$
}

\begin{abstract}
ABSTRAK
Penelitian stok teripang dan lingkungan perairannya telah dilakukan pada musim peralihan barat ke timur (Mei 2002), musim timur (Juni 2002), musim peralihan timur ke barat (September 2002), dan musim barat (Desember 2002). Penelitian dilakukan di wilayah Gugusan Pulau Kelapa dalam kawasan Taman Nasional Laut Kepulauan Seribu. Sebagai stasiun penelitian yaitu perairan Pulau Pamegaran dan Pulau Panjang Kecil (Zona Pemanfaatan Tradisional) serta perairan Pulau Kayu Angin Bira (Zona Inti). Tujuan dari penelitian yaitu memperoleh data dan informasi tentang kepadatan, pola sebaran, dan komposisi jenis teripang serta karakteristik fisika-kimia dan biologi perairan. Pengamatan stok teripang untuk menentukan kepadatan, pola sebaran dan komposisi jenis dilakukan dengan cara transek kuadran. Parameter fisika-kimia dan biologi perairan yang diamati meliputi kedalaman, kecerahan, suhu, arus, salinitas, oksigen terlarut, pH, fitoplankton, dan zooplanton. Hasil penelitian menunjukkan bahwa di perairan Kepulauan Seribu ditemukan lima belas jenis teripang. Kepadatan stok berkisar antara 120-2.330 ind/ha. Pola penyebaran teripang merata dan tidak ada spesies yang mendominasi. Karakteristik fisika-kimia dan biologi perairan sesuai dengan habitat teripang dan masih dalam batas optimal untuk pertumbuhan teripang. Hasil analisis komponen utama (PCA) menunjukkan bahwa ada kecenderungan kepadatan stok teripang dipengaruhi oleh kedalaman perairan dan kecepatan arus.
\end{abstract}

ABSTRACT: Density, biodiversity, and environment of sea cucumbers in Kelapa Island of Seribu Island. By: Sri Turni Hartati and Indar Sri Wahyuni

Study on sea cucumbers stock and their environment in Seribu Island was carried out in inter monsoon west to east (May 2002), east monsoon (June 2002), inter monsoon east to west (September 2002), and in west monsoon (December 2002). The site of the study was performed in National Marine Conservation of Seribu Island, i.e., Pamegaran Island and Panjang Kecil Island waters (Traditional Exploitation Zone) and Kayu Angin Bira Island waters (Central Zone). The aim of this study is to obtain data and information on stock abundance, distribution, and species composition of sea cucumber as well as the characteristic of physicochemist and biology of the environment. The observation was done by transect quadrant model. The observed parameters of physico-chemist and biology of the waters are depth, transparancy, temperature, current, salinity, dissolved of oxygen, $\mathrm{pH}$, phytoplankton, and zooplankton. The results show that in Seribu Island waters a number of 15 species of sea cucumbers was found with densities between 120-2.330 ind/ha. The sea cucumbers are evenly distributed among the species. Physico-chemist and biological characteristics of water are in the range of life and growth tolerable sea cucumbers. The result of principal component analysis (PCA) shows that sea cucumber stock density is influenced by the water depth and current velocity.

KEYWORDS: $\quad$ sea cucumber, stock, environment, Seribu Island

\section{PENDAHULUAN}

Teripang adalah salah satu komoditas perikanan yang mempunyai prospek cukup baik dan bernilai ekonomis tinggi, baik di pasar lokal maupun internasional. Jenis biota ini dikenal pula dengan nama ketimun laut, sea cucumber (Inggris), namako (Jepang), beche-de-mer (Perancis) atau dalam istilah pasar internasional dikenal dengan nama teat fish (Sutaman, 1993; Martoyo et. al., 1996):

Teripang dipasarkan dalam beberapa bentuk produk di antaranya adalah teripang kering (beche-de-mer), usus asin (konowata), gonad kering (konoko), teripang kaleng, dan kerupuk teripang. Indonesia adalah salah satu negara pemasok teripang di pasaran internasional. Pasaran utama teripang dari Indonesia di antaranya adalah Jepang, Hongkong, Korea, Taiwan, Cina, Thailand, Singapura, dan Malaysia (Ditjen Perikanan, 1995).

Perkembangan ekspor teripang Indonesia dari tahun ke tahun terus meningkat. Berdasarkan pada data ekspor dari Direktorat Jenderal Perikanan tahun 1988, ekspor teripang pada tahun 1984 berjumlah 1.318 .100 $\mathrm{kg}$ dan pada tahun 1988 meningkat hampir tiga kali lipat, yaitu menjadi $3.408 .100 \mathrm{~kg}$. Sedangkan nilainya naik hampir delapan kali lipat, yaitu dari US \$ 1.547.945 pada tahun 1984 menjadi US\$ 8.266.262 pada tahun 1988. Namun sejak tahun 1989 sudah terlihat adanya kecenderungan penurunan volume ekspor teripang yaitu hanya sekitar $2.449 .268 \mathrm{~kg}$ dengan nilai US\$ 6.733.406 (Ditjen Perikanan, 1989,1995).

\footnotetext{
") Peneliti pada Balai Riset Perikanan Laut, Jakarta
} 
Harga teripang yang tinggi tersebut mendorong nelayan untuk menangkapnya dalam jumlah besar. Hal ini menempatkan Indonesia pada posisi teratas dari negara-negara penghasil teripang di dunia (Tuwo \& Nessa, 1991; Tuwo \& Conand, 1992).

Ekspor teripang dari Indonesia sebagian besar masih mengandalkan penangkapan dari alam. Aktivitas penangkapan yang dilakukan terus menerus di alam akan mengancam kelestarian sumber daya dan gejala ini sudah terlihat di beberapa daerah penangkapan.

Kepulauan Seribu yang terletak di utara Jakarta memiliki beberapa wilayah perairan yang merupakan habitat teripang. Komoditas teripang tersebut telah diusahakan oleh nelayan sejak tahun 1973. Sebelum Kepulauan Seribu ditetapkan sebagai Taman Nasional Laut yang merupakan kawasan konservasi yaitu pada tahun 1986, tingkat pengusahaan teripang sangat intensif. Hasil tangkapan nelayan dapat mencapai 1.000 ekor dalam satu hari. (Azkab \& Hutomo,1986). Akibat aktivitas penangkapan yang berlebihan tersebut pada saat ini populasinya semakin menurun, bahkan untuk beberapa spesies yang bernilai ekonomis penting cenderung punah, seperti teripang pasir (Holuthuria scabra). Menurut Teswara (1995), kepadatan teripang di perairan Kepulauan Seribu pada musim peralihan 1 dan musim peralihan 2 berkisar antara $0,147-0,341 \mathrm{ind} / \mathrm{m}^{2}$. Jenis teripang didominasi oleh teripang getah coklat (Holothuria leucospilota), teripang sabuk raja (Synapta maculata), dan teripang olok-olok (Bohadschia marmorata). Teripang pasir (Holothuria scabra) dan teripang bilalo (Actinopyga echinites) yang mempunyai nilai ekonomis tinggi kehadirannya sangat rendah. Hasil pengamatan terhadap kondisi lingkungan perairan, beberapa wilayah perairan Kepulauan Seribu masih mendukung sebagai habitat teripang. Suhu berkisar antara $26-31^{\circ} \mathrm{C}$, salinitas $29-$ $34 \%$ dan $\mathrm{pH} 6,5-8,5$. Dasar perairan terdiri dari pasir yang berasosiasi dengan algae, karang hidup, pecahan karang, sea grass (rumput laut), dan karang mati.

Salah satu upaya untuk memulihkan dan meningkatkan populasi sumber daya teripang di perairan Kepulauan Seribu yaitu dengan melalui pengkayaan stok (stock enhancement). Dengan kondisi lingkungan perairan yang mendukung, usaha pengkayaan stok di perairan Kepulauan Seribu dapat dilakukan dengan mentransplantasikan benih teripang dari alam maupun dari hasil pemijahan buatan.

Untuk menunjang keberhasilan usaha pemacuan stok tersebut perlu dilakukan penelitian untuk memperoleh data dan informasi dasar tentang stok teripang dan kondisi lingkungan perairannya.

Tujuan dari penelitian yang dilakukan yaitu memperoleh data dan informasi tentang kepadatan, pola sebaran, dan komposisi jenis teripang serta karakteristik fisika-kimia dan biologi perairannya.

\section{BAHAN DAN METODE}

Penelitian dilakukan di Taman Nasional Laut Kepulauan Seribu pada musim peralihan barat ke timur (Mei 2002), musim timur (Juni 2002), musim peralihan timur ke barat (September 2002), dan musim barat (Desember 2002). Pulau Pamegaran dan perairan Pulau Panjang Kecil (Zona Pemanfaatan Tradisional) serta perairan Pulau Kayu Angin Bira (Zona Inti) ditentukan sebagai stasiun penelitian. Perairan $P$. Pamegaran terletak pada posisi $05^{\circ} 38^{\prime} 02,4^{\prime \prime}$ LS dan $106^{\circ} 36^{\prime} 35,1^{\prime \prime}$ BT, Pulau Panjang Kecil pada posisi $05^{\circ} 39^{\prime} 18,2^{\prime \prime}$ LS dan $106^{\circ} 34^{\prime} 39,9^{\prime \prime}$ BT dan P. Kayu Angin Bira pada posisi $05^{\circ} 36^{\prime} 04^{\prime \prime}$ LS dan $106^{\circ} 33^{\prime} 56^{\prime \prime}$ BT.

Tahapan penelitian meliputi kegiatan pengumpulan data, tabulasi data, pengolahan data, analisa data, dan penulisan laporan.

\section{Pengumpulan Data}

1. Pengamatan stok teripang untuk menentukan kelimpahan, pola sebaran, dan komposisi jenis dilakukan dengan cara transek kuadran.

2. Pengamatan parameter fisika-kimia dan biologi perairan meliputi kedalaman, kecerahan, suhu, arus, salinitas, oksigen terlarut, $\mathrm{pH}$, fitoplankton, dan zooplankton.

\section{Prosedur Transek Kuadran}

- Transek kuadran dilakukan di tiga wilayah perairan yang telah ditentukan sebagai stasiun penelitian ( $P$. Pamegaran, P. Panjang Kecil, dan P. Kayu Angin Bira).

- Garis transek ditetapkan dari pantai ke arah tubir sepanjang $50 \mathrm{~m}$ dan lebar $20 \mathrm{~m}$. Dengan demikian area untuk transek teripang seluas $1.000 \mathrm{~m}^{2}$ untuk masing-masing stasiun penelitian.

- Pada area seluas $1.000 \mathrm{~m}^{2}$ tersebut, pengamatan teripang dilakukan secara sensus, diidentifikasi, dan dihitung kelimpahannya.

\section{Analisis Data}

\section{Kepadatan Teripang}

Kepadatan adalah jumlah individu teripang per satuan luas. Kepadatan masing-masing jenis teripang yang ada di setiap stasiun penelitian dihitung berdasarkan rumus:

$$
\mathrm{X}=\frac{\sum \mathrm{X}_{\mathrm{i}}}{\mathrm{n}}
$$

di mana:

$X \quad$ : rata-rata jumlah teripang per satuan luas

$\Sigma x_{i} \quad$ : jumlah teripang dalam satuan contoh

n : jumlah luas satuan contoh 


\section{Anallsa Keanekaragaman}

Indeks keanekaragaman adalah suatu gambaran secara matematik yang melukiskan struktur komunitas suatu organisme yang dapat mempermudah menganalisis informasi tentang jenis dan jumlah jenis organisme tersebut. Perhitungan indeks keanekaragaman dilakukan dengan menggunakan rumus Shannon-Wiener (Magurran, 1955):

$$
\mathrm{H}^{\prime}=-\sum_{i=1}^{s} p i \ln p i
$$

Keterangan:

$$
\begin{array}{ll}
\mathrm{H}^{\prime} & \text { : Indeks keanekaragaman Shannon-Wiener } \\
\mathrm{pi} & \text { : ni/N } \\
\mathrm{ni} & : \text { jumlah individu jenis ke- } \mathrm{i} \\
\mathrm{N} & : \text { jumlah total individu jenis ke-i } \\
\mathrm{s} & \text { : jumlah jenis biota; } I=1,2,3, \ldots \ldots \ldots, \mathrm{s}
\end{array}
$$

Indeks keanekaragaman

Shannon-Wiener dikategorikan sebagai berikut:

$H^{\prime}<1$ : keanekaragaman rendah

$1<H^{\prime}<3$ : keanekaragaman sedang

$H^{\prime}>3$ : keanekaragaman tinggi

\section{Analisa Keseragaman}

Indeks keseragaman dapat dihitung menurut rumus Krebs (1989) sebagai berikut:

$$
E=\frac{H^{\prime}}{H m a k s}
$$

di mana:

$$
\begin{array}{ll}
\mathrm{E} & \text { : indeks keseragaman } \\
\mathrm{H}^{\prime} & \text { : indeks keanekaragaman } \\
\mathrm{Hmaks} & : \log _{2} \mathrm{~s}
\end{array}
$$

Nilai indeks keseragaman ini berkisar antara 0-1. Indeks keseragaman' mendekati nilai nol, berarti dalam ekosisitem tersebut ada kecenderungan terjadi dominansi spesies yang disebabkan oleh adanya ketidakstabilan faktor-faktor lingkungan dan populasi. Bila indeks keseragaman mendekati 1, maka ekosistem tersebut dalam kondisi yang relatif mantap, yaitu jumlah individu tiap spesies relatif sama (Bower \& Zar, 1977).

\section{Indeks Dominansi}

Menurut Odum (1971), indeks dominansi dapat dirumuskan sebagai berikut:

$C=\sum\left(\frac{n_{1}}{N}\right)^{2}$

di mana:
C : indeks dominansi
$n_{i} \quad$ : jumlah satuan pengambilan contoh
$\mathrm{N}$ : jumlah total individu

Nilai indeks dominansi berkisar antara 0-1. Jika indeks dominansi mendekati 0 berarti hampir tidak ada individu yang mendominasi dan biasanya diikuti dengan indeks keseragaman yang besar. Jika indeks dominansi mendekati 1 , berarti ada salah satu spesies yang mendominasi dan diikuti dengan nilai indeks keseragaman yang semakin kecil (Odum, 1971).

\section{Indeks Sebaran Morishita}

Untuk menghitung pola sebaran digunakan indeks penyebaran Morishita (Brower \& Zar, 1977) dengan rumus sebagai berikut:

$$
I \delta=\frac{n_{i} \sum\left(X_{i}\left(X_{i}-1\right)\right)}{N(N-1)}
$$

di mana:

$$
\begin{array}{ll}
\text { Iס } & \text { : Indeks sebaran Morishita } \\
n_{i} & \text { : jumlah satuan pengambilan contoh } \\
N & \text { : jumlah total individu } \\
X_{i} & \text { : jumlah individu spesies pada pengambilan } \\
& \text { contoh ke-i }
\end{array}
$$

Jika:

$1 \delta>1$ : pola sebaran jenis individu bersifat mengelompok

$I \delta=1$ : pola sebaran jenis individu bersifat acak

$10<1$ : pola sebaran jenis individu bersifat seragam

\section{Analisa komponen utama}

Untuk dapat melihat karakteristik dari parameterparameter yang diukur dan mengetahui apakah terdapat pengelompokan stasiun menurut parameterparameter tersebut, maka digunakan Analisis Komponen Utama dengan menggunakan Software Statistika 99.

Langkah-langkah yang diperlukan 'dalam analisis komponen utama atau Prinsipal Component Analisis (PCA) adalah sebagai berikut (Bengen, 2000):

a. Suatu individu dapat dijelaskan dengan baik oleh nilai-nilai yang diperoleh dari $p$ variabel.

b. Sumbu-sumbu faktorial (komponenkomponen utama) yang diperoleh menggambarkan kombinasi linier dari variabel-variabel asal.

c. Untuk menemukan kembali informasi yang lengkap, maka perlu diperhatikan semua sumbu yang jumlahnya sama dengan jumlah variabel (kecuali terdapat suatu korelasi yang sempurna antar variabel).

Secara umum informasi yang diberikan dari hasil Analisis Komponen Utama adalah sebagai berikut: Dari sudut pandang variabel:

- matriks korelasi antar semua variable,

- akar ciri dari setiap sumbu faktorial: berkaitan dengan jumlah pengaruh dari setiap individu, 
- vektor ciri yang menjelaskan koefisien variabel pemusatan dan pereduksian dalam persamaan linier yang mendeterminasikan sumbu-sumbu utama,

- grafik bidang (Sumbu $1 /$ Sumbu 2/ ...) yang memvisualisasikan variabel terhadap sumbu.

Dari sudut pandang individu:

- koordinat individu pada setiap sumbu,

- kualitas representasi titik dalam setiap grafik bidang (kontribusi relatif),

- grafik bidang yang memperlihatkan kemiripan (kedekatan) antar titik individu,

\section{HASIL BAHASAN}

\section{Stok Teripang}

Stok teripang di perairan Kepulauan Seribu ada 15 jenis (Tabel 1). Empat jenis di antaranya tidak dikonsumsi yaitu: Euapta godeffroyi, Holothuria hilla, Holothuria pervicax, dan Synapta maculata. Sebelas jenis teripang lainnya adalah jenis yang dikonsumsi, yaitu: Actinopyga miliaris, Actinopyga sp, Bohadschia marmorata, Bohadschia sp, Bohadschia similis, Holothuria edulis, Holothuria impatiens, Holothuria leucospilota, Holothuria sp, Stichopus horrens, dan Stichopus variegatus (Gambar 1). Dua jenis teripang yang terakhir yaitu Stichopus horrens dan Stichopus variegatus bernilai ekonomis tinggi, dengan harga di tingkat nelayan mencapai Rp. 120.000,-/kg teripang kering dan di tingkat penampung Rp. 150.000,-/kg. Sembilan jenis teripang lainnya harganya berkisar antara Rp.8.500,- sampai Rp.10.000,- per kilo gram.

Hasil pengamatan kepadatan teripang disajikan pada Tabel 1. Kepadatan teripang berkisar antara 120-2.330 ind/ha. Kepadatan ini relatif lebih rendah dibandingkan penelitian yang dilakukan oleh Teswara (1995) pada lokasi yang sama, yaitu berkisar antara 1.470-3.410 ind/ha. Dari hasil transek terlihat bahwa kepadatan teripang relatif tinggi berlangsung antara musim timur sampai musim peralihan timur ke barat, yaitu pada kisaran 990-2.330 ind/ha. Memasuki musim barat kepadatannya mulai menurun yaitu 570600 ind/ha, hanya di perairan P. Kayu Angin Bira yang kepadatannya masih relatif tinggi, yaitu 1.750 ind/ha. Pulau Kayu Angin Bira ini masuk dalam Zona Inti kawasan Taman Nasional Laut Kepulauan Seribu, sehingga perairannya tidak bisa diusahakan oleh nelayan. Kepadatan teripang relatif rendah terjadi pada musim peralihan barat ke timur, yaitu $120 \mathrm{ind} / \mathrm{ha}$ di perairan $P$. Pamegaran.

Jenis teripang yang selalu hadir pada setiap waktu dan stasiun pengamatan adalah jenis yang tidak bernilai ekonomis, yaitu Euapta godeffroyi dan Holothuria hilla. Stichopus variegatus yang nilai ekonomisnya tinggi hanya hadir di perairan Pulau Kayu Angin Bira pada waktu musim timur, dengan kepadatan $10 \mathrm{ind} / \mathrm{ha}$. Stichopus horrens hadir di setiap stasiun pengamatan, dengan kepadatan antara 10-150 ind/ha, kecuali: di perairan Pulau Kayu Angin Bira pada waktu musim barat.

Hasil analisa keanekaragaman, keseragaman, dominansi, dan penyebaran morisita untuk mengetahui struktur komunitas teripang disajikan pada Tabel 2.

Hasil pengamatan menunjukkan nilai indeks keanekaragaman berkisar antara 1,645-2,873. Kisaran nilai tersebut menunjukkan bahwa keanekaragaman jenis teripang di perairan Kepulauan Seribu sedang, yang berarti bahwa ekosistem perairan Kepulauan Seribu relatif stabil untuk pertumbuhan teripang. Indeks keanekaragaman stasiun 1 antara bulan Mei dan Desember fluktuasinya sangat tajam, karena pada umumnya di perairan Kepulauan Seribu musim penangkapan teripang berlangsung pada musim barat (DesemberFebruari), dengan kondisi surut rendah dan jenis-jenis teripang yang ditemukan relatif banyak. Hartati et al (2002) menyatakan bahwa stok teripang di perairan Pulau Pramuka (lokasi berdekatan dengan Gugusan Pulau Kelapa) stok teripang relatif rendah terjadi pada musim timur dan hanya ditemukan lima jenis teripang.

Indeks keseragaman menunjukkan nilai yang relatif tinggi, yaitu pada kisaran 0,519-0,906. Nilai tersebut menunjukkan adanya suatu penyebaran jumlah individu yang merata dengan tidak adanya spesies yang mendominasi. Kondisi ini juga bisa dilihat dari nilai indeks dominansi yang rendah, yaitu berkisar antara 0,154-0,441.

Nilai indeks sebaran Morisita berkisar antara 0,254-0,702, yang menunjukkan bahwa terjadi penyebaran individu yang bersifat seragam, artinya bahwa distribusi spesies di setiap stasiun pengamatan cukup merata. Kondisi ini juga dapat diartikan bahwa setiap spesies mempunyai kesempatan yang sama untuk hidup di setiap stasiun pengamatan.

Hasil analisis struktur komunitas menunjukkan bahwa di perairan Kepulauan Seribu dapat dilakukan usaha budi daya (pembesaran) maupun pengkayaan stok sumber daya teripang. Pemilihan jenis teripang untuk budi daya maupun untuk kegiatan pengkayaan stok tidak harus selektif, akan lebih menguntungkan apabila yang digunakan adalah jenis yang bernilai ekonomis tinggi, misalnya Stichopus variegatus atau Holothuria scabra.

\section{Karakteristik Fisika-Kimia dan Biologi Perairan}

Hasil pengamatan parameter fisika, kimia, dan biologi perairan di sajikan pada Tabel 3. Ke tiga stasiun pengamatan merupakan perairan yang sangat jernih, sampai kedalaman $5 \mathrm{~m}$ kecerahannya mencapai $100 \%$. Suhu perairan bervariasi pada kisaran $28,77-30,60^{\circ} \mathrm{C}$. Variasi suhu ini masih dalam 


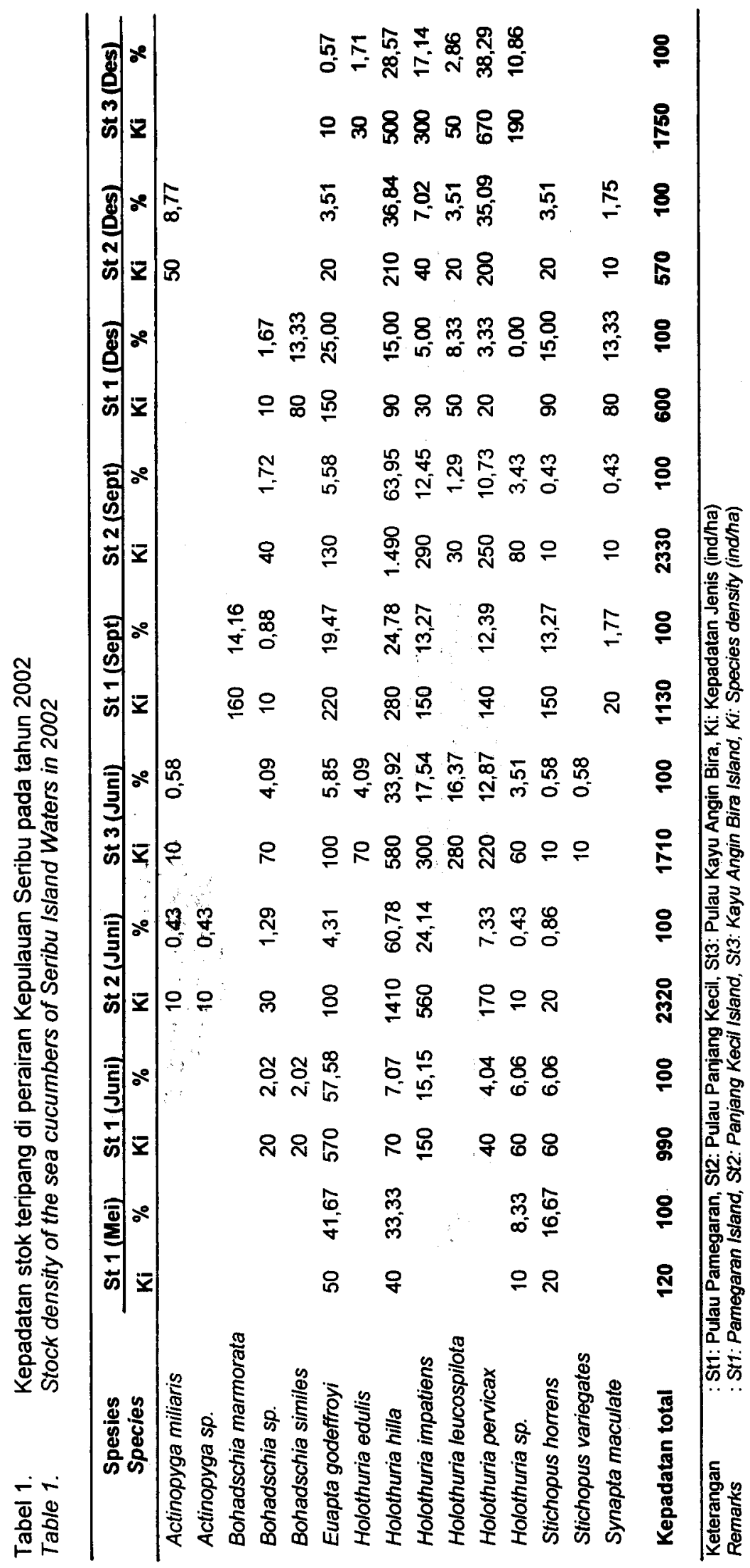



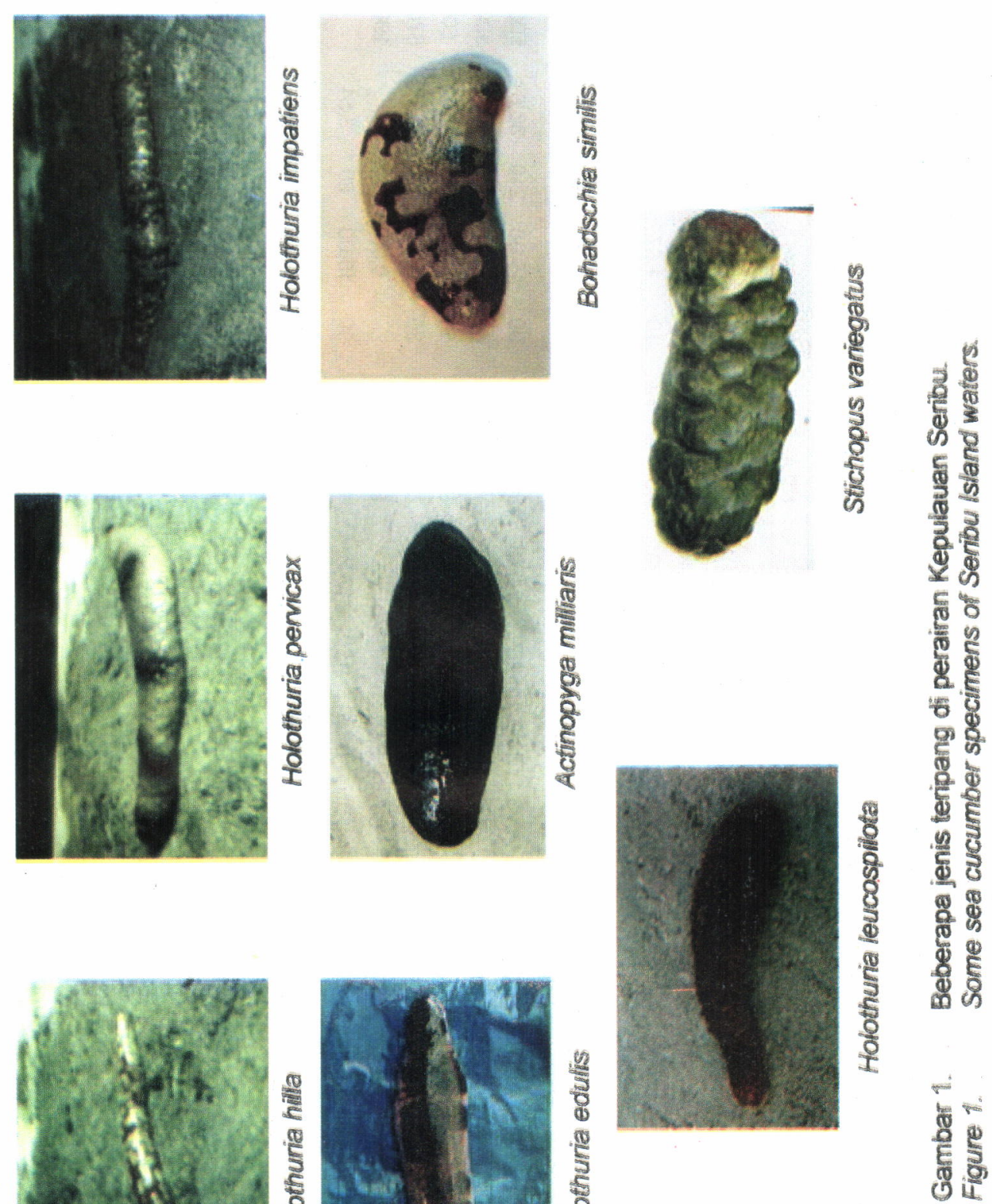

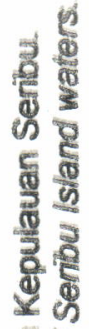
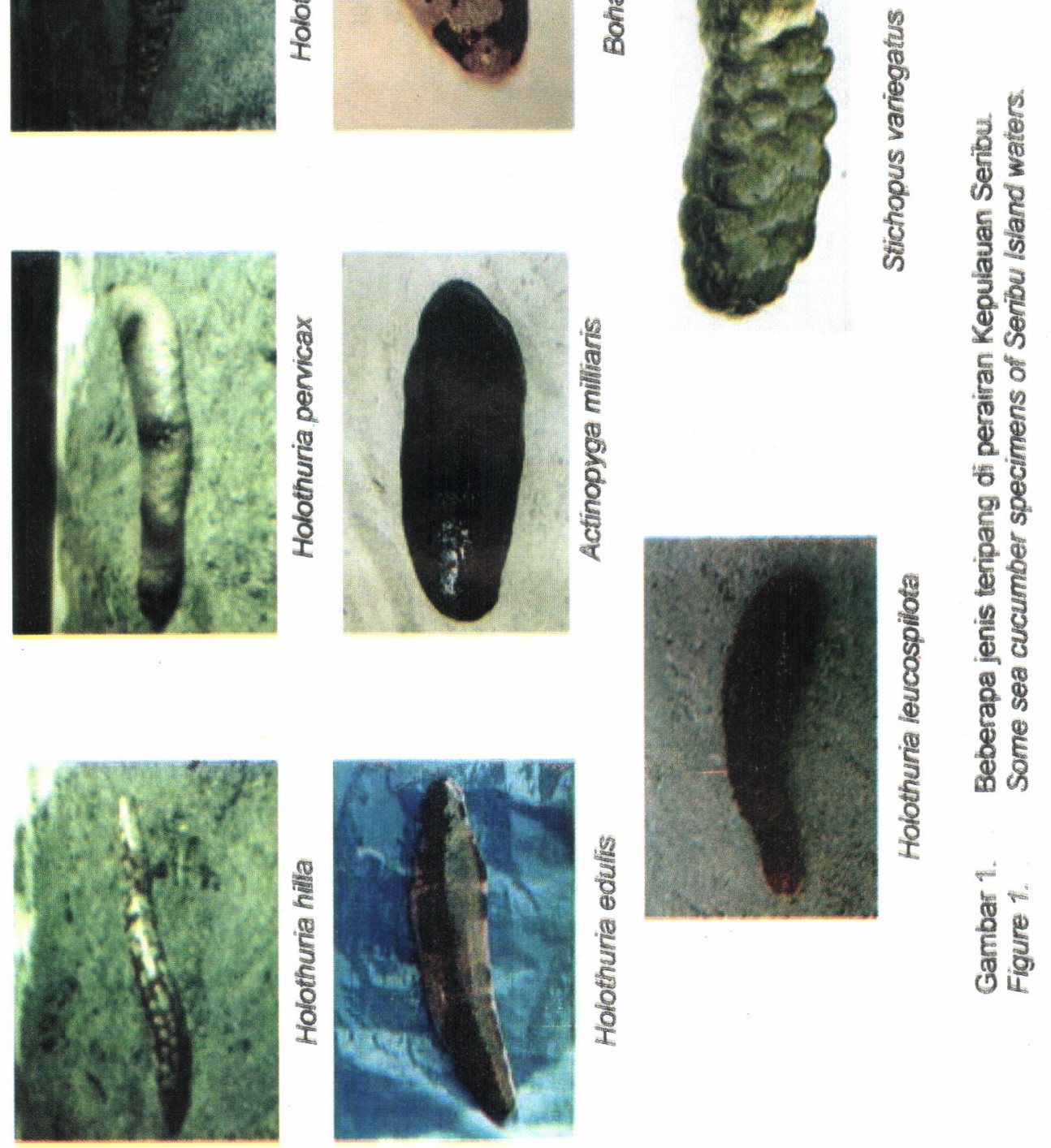
Tabel 2. Hasil analisis struktur komunitas teripang di perairan Kepulauan Seribu Table 2. Community structure of sea cucumbers in Seribu Island waters

\begin{tabular}{clrrrr}
\hline $\begin{array}{c}\text { Stasiun } \\
\text { Station }\end{array}$ & \multicolumn{1}{c}{$\begin{array}{c}\text { Bulan } \\
\text { Month }\end{array}$} & H' & E & C & I \\
\hline 1 & Mei/May & 1,784 & 0,892 & 0,319 & 0,606 \\
& Juni/June & 2,046 & 0,682 & 0,369 & 0,410 \\
& September/September & 2,668 & 0,889 & 0,170 & 0,370 \\
& Desember/December & 2,873 & 0,906 & 0,154 & 0,254 \\
& Juni/June & 1,645 & 0,519 & 0,435 & 0,487 \\
& September/September & 1,781 & 0,562 & 0,441 & 0,555 \\
& Desember/December & 2,249 & 0,750 & 0,275 & 0,702 \\
& Juni/June & 2,694 & 0,779 & 0,197 & 0,310 \\
& Desember/December & 2,120 & 0,755 & 0,271 & 0,472 \\
\hline
\end{tabular}

\section{Keterangan/Note:}

St1 : Pulau Pamegaran/Pamegaran Island

St2 : Pulau Panjang Kecil/Panjang Kecil Island

St3 : Pulau Kayu Angin Bira/Kayu Angin Bira Island

Tabel 3. Karakteristik fisika-kimia dan biologi perairan Kepulauan Seribu tahun 2002

Table 3. Characteristic of physico-chemist and biology of Seribu Island waters in 2002

\begin{tabular}{|c|c|c|c|c|c|c|c|c|c|}
\hline $\begin{array}{l}\text { Parameter } \\
\text { Parameters }\end{array}$ & $\begin{array}{c}\text { S1 } \\
\text { (Mei) }\end{array}$ & $\begin{array}{c}\text { S1 } \\
\text { (Juni) }\end{array}$ & $\begin{array}{c}\text { S2 } \\
\text { (Juni) }\end{array}$ & $\begin{array}{c}\text { S3 } \\
\text { (Juni) }\end{array}$ & $\begin{array}{c}\text { S1 } \\
\text { (Sept) }\end{array}$ & $\begin{array}{c}\text { S2 } \\
\text { (Sept) }\end{array}$ & $\begin{array}{c}\text { S1 } \\
\text { (Des) }\end{array}$ & $\begin{array}{c}\text { S2 } \\
\text { (Des) }\end{array}$ & $\begin{array}{c}\text { S3 } \\
\text { (des) }\end{array}$ \\
\hline \multicolumn{10}{|l|}{ Fisika/Physic } \\
\hline $\begin{array}{l}\text { Kedalaman } \\
\text { (m) }\end{array}$ & 2,90 & 2,75 & 4,32 & 3,69 & 2,95 & 4,10 & 2,00 & 3,00 & 5,00 \\
\hline $\begin{array}{l}\text { Kecerahan }(\%) \\
\text { Suhu }\left({ }^{\circ} \mathrm{C}\right)\end{array}$ & $\begin{array}{c}100 \\
29,47\end{array}$ & $\begin{array}{c}100 \\
29,42\end{array}$ & $\begin{array}{c}100 \\
28,77\end{array}$ & $\begin{array}{c}100 \\
28,83\end{array}$ & $\begin{array}{c}100 \\
28,92\end{array}$ & $\begin{array}{c}100 \\
28,77\end{array}$ & $\begin{array}{c}100 \\
30,52\end{array}$ & $\begin{array}{c}100 \\
30,60\end{array}$ & $\begin{array}{c}100 \\
30,24\end{array}$ \\
\hline $\begin{array}{l}\text { Kecepatan } \\
\text { Arus (m/det) }\end{array}$ & 0,12 & 0,13 & 0,30 & 0,12 & 0,13 & 0,30 & 0,13 & 0,13 & 0,14 \\
\hline \multicolumn{10}{|c|}{ Kimia/Chemistry } \\
\hline $\begin{array}{l}\text { Salinitas (\%o) } \\
\mathrm{pH} \\
\mathrm{DO}(\mathrm{ppm})\end{array}$ & $\begin{array}{c}33,00 \\
7,89 \\
6,03\end{array}$ & $\begin{array}{c}33,00 \\
7,21 \\
7,75\end{array}$ & $\begin{array}{c}33,00 \\
7,88 \\
5,10 \\
\end{array}$ & $\begin{array}{c}34,00 \\
7,83 \\
8,30\end{array}$ & $\begin{array}{c}33,00 \\
7,90 \\
5,53\end{array}$ & $\begin{array}{c}33,00 \\
7,88 \\
5,10 \\
\end{array}$ & $\begin{array}{c}33,00 \\
7,82 \\
7,89 \\
\end{array}$ & $\begin{array}{c}32,00 \\
7,75 \\
6,23 \\
\end{array}$ & $\begin{array}{c}33,00 \\
7,75 \\
6,14\end{array}$ \\
\hline \multicolumn{10}{|l|}{ Biologi/Biology } \\
\hline $\begin{array}{l}\text { Fitoplankton } \\
\left(\text { cell } / \mathrm{m}^{3}\right)\end{array}$ & 826000 & 599200 & 1277400 & 2108466 & 207480 & 216920 & 96000 & 136000 & 358000 \\
\hline $\begin{array}{l}\text { Zooplankton } \\
\text { (ind } / \mathrm{m}^{3} \text { ) }\end{array}$ & 174286 & 223048 & 301143 & 342952 & 75520 & 93640 & 57143 & 85714 & 117143 \\
\hline
\end{tabular}

Keterangan/Note:

S1 : Pulau Pamegaran/Pamegaran Island

S2 : Pulau Panjang Kecil/Panjang Kecil Island

S3 : Pulau Kayu Angin Bira/Kayu Angin Bira Island

kisaran suhu optimal untuk pertumbuhan teripang. Beberapa parameter lingkungan yang lain, seperti, salinitas, $\mathrm{pH}$, dan oksigen terlarut nilai kisarannya juga masih dalam batas optimal untuk pertumbuhan teripang, kecuali arus atau gerakan air yang lebih lambat. Kecepatan arus berkisar antara 0,12-0,30 $\mathrm{m} /$ detik. Untuk pertumbuhan teripang yang optimal diperlukan kecepatan arus berkisar antara 0,3-0,5 $\mathrm{m} /$ detik. Kecepatan arus relatif tinggi hanya dijumpai di stasiun 2, yaitu di perairan $P$. Panjang kecil, yaitu $0,30 \mathrm{~m} /$ detik. Kisaran nilai oksigen terlarut, salinitas, dan $\mathrm{pH}$ perairan Kepulauan Seribu adalah 5,10-8,30, $32-33 \%$, dan $7,2-7,88$. Kisaran nilai optimal yang dibutuhkan untuk pertumbuhan teripang, oksigen terlarut berkisar antara 4-8 ppm, salinitas $28-32 \%$ dan $\mathrm{pH} 6,5-8,5$. Kepadatan fitoplankton dan zooplankton yang merupakan makanan utama teripang berkisar antara $136.000 \mathrm{sel} / \mathrm{m}^{2}-2.108 .466$ $\mathrm{sel} / \mathrm{m}^{2}$ dan zooplankton berkisar antara 57.143 ind $/ \mathrm{m}^{2}-342.952 \mathrm{ind} / \mathrm{m}^{2}$. Hasil pengamatan parameter fisika-kimia dan biologi menunjukkan bahwa kondisi lingkungan perairan Kepulauan Seribu sesuai dengan habitat teripang.

\section{Sebaran Karakteristik Fisika-Kimia dan Biologi Perairan serta Kepadatan Stok Teripang}

Hasil analisis komponen utama (PCA) untuk mendeterminasi sebaran karakteristik fisika-kimia dan biologi perairan serta kepadatan stok teripang antar stasiun pengamatan disajikan pada Gambar 2 dan Tabel 4. Parameter-parameter kedalaman, suhu, arus, salinitas, $\mathrm{pH}$, oksigen terlarut, kepadatan fitoplankton, kepadatan zooplankton, dan kepadatan 
teripang terpusat pada dua sumbu utama, yaitu $F 1$ dan F2. Masing-masing sumbu menjelaskan 42,09\% dan $29,44 \%$. Total keragaman data yang dijelaskan oleh kedua sumbu adalah $71,53 \%$ (Gambar 2). Parameter yang terletak di sebelah kiri sumbu faktor 2 memiliki hubungan yang terbalik dengan parameter yang terletak di sebelah kanan sumbu faktor 2 . Terlihat bahwa kepadatan fitoplankton, zooplankton, salinitas, kedalaman, kepadatan teripang, arus, dan $\mathrm{pH}$ memiliki korelasi negatif dengan kandungan oksigen terlarut dan suhu. Salinitas mempunyai korelasi positif dengan kepadatan fitoplankton dan

Tabel 4. Matriks korelasi antara parameter fisika-kimia dan biologi perairan serta kepadatan stok teripang di Kepulauan Seribu

Table 4. Corelation matrix between parameters of physico-chemist and biology of water, and stock density of sea cucumbers of Seribu Island waters

\begin{tabular}{|c|c|c|c|c|c|c|c|c|c|}
\hline & Kepadatan & Kedalaman & Suhu & Arus & Salinitas & $\mathrm{pH}$ & DO & Fitoplankton & Zooplankton \\
\hline Kepadatan & 1 & 0,7852 & $-0,5789$ & 0,7652 & 0,3602 & 0,1498 & $-0,3541$ & 0,3079 & 0,3578 \\
\hline Kedalaman & 0,7852 & 1 & $-0,3042$ & 0,5111 & 0,1848 & 0,1646 & $-0,4695$ & 0,2707 & 0,2968 \\
\hline Suhu & $-0,5789$ & $-0,3042$ & 1 & $-0,5084$ & $-0,5800$ & $-0,1936$ & 0,2905 & $-0,5402$ & $-0,5534$ \\
\hline Arus & 0,7652 & 0,5111 & $-0,5084$ & 1 & $-0,0330$ & 0,2834 & $-0,6421$ & 0,0361 & 0,1453 \\
\hline Salinitas & 0,3602 & 0,1848 & $-0,5800$ & $-0,0330$ & 1 & 0,0918 & 0,4225 & 0,7357 & 0,6169 \\
\hline $\mathrm{pH}$ & 0,1498 & 0,1646 & $-0,1936$ & 0,2834 & 0,0918 & 1 & $-0,4617$ & 0,0888 & $-0,1419$ \\
\hline DO & $-0,3541$ & $-0,4695$ & 0,2905 & $-0,6421$ & 0,4225 & $-0,4617$ & 1 & 0,3211 & 0,2669 \\
\hline Fitoplankton & 0,3079 & 0,2707 & $-0,5402$ & 0,0361 & 0,7357 & 0,0888 & 0,3211 & 1 & 0,9456 \\
\hline Zooplankton & 0,3578 & 0,2968 & $-0,5534$ & 0,1453 & 0,6169 & $-0,1419$ & 0,2669 & 0,9456 & 1 \\
\hline
\end{tabular}
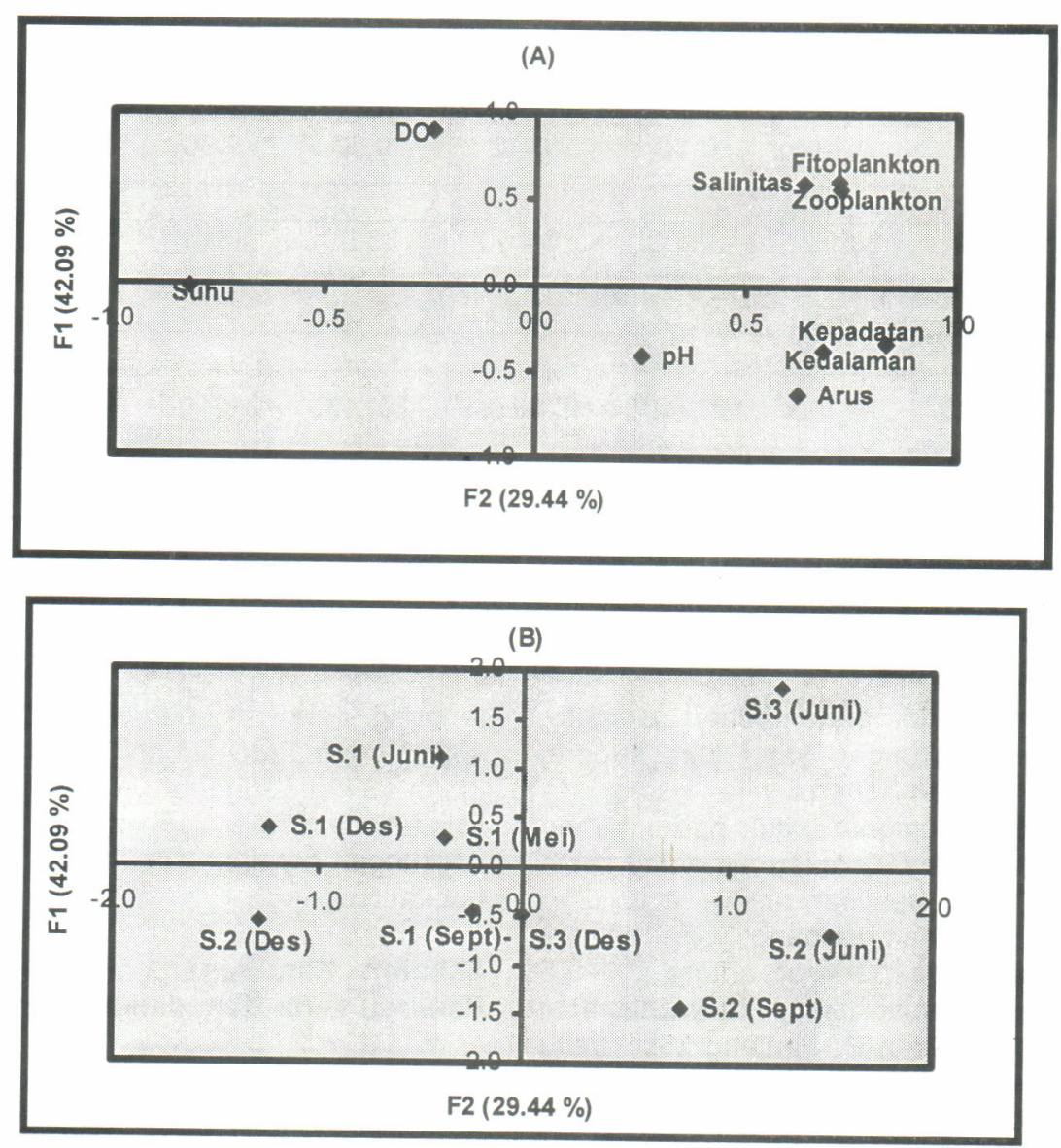

Gambar 2. Analisis Komponen Utama (PCA) parameter lingkungan dan kepadatan stok teripang antar

Figure 2 Stasiun pengamatan di perairan Kepulauan Seribu.

Figure 2. Result of Principal Component Analysis (PCA) for environmental parameters and stock density of Sea Cucumber in Seribu Island waters. 
zooplankton. Kedalaman dan kepadatan stok teripang letaknya berdekatan, yang berarti ada kecenderungan bahwa kepadatan stok teripang dipengaruhi oleh kedalaman perairan. Demikian juga dengan faktor kecepatan arus, mempunyai pengaruh positif terhadap kepadatan stok teripang. Kondisi ini dapat dilihat dari matriks korelasi antara parameter fisikakimia dan biologi perairan serta kepadatan stok teripang (Tabel 4). Korelasi antara kepadatan stok teripang dengan kedalaman perairan dan kecepatan arus nilainya mendekati satu, yaitu 0,7852 dan 0,7652 . Pada perairan yang lebih dalam kepadatan stok teripang cenderung lebih tinggi, karena nelayan setempat dalam upaya menangkap teripang hanya tergantung pada saat perairan surut (daerah dangkal), kecuali nelayan dari daerah Madura yang usaha penangkapannya dengan cara menyelam. Kepadatan stok teripang juga dipengaruhi oleh kecepatan arus, karena pada perairan yang kecepatan arusnya relatif sedang sirkulasi makanan yang berupa fitoplankton dan zooplankton akan lebih lancar. Pada matriks korelasi juga terlihat bahwa nilai korelasi antara kepadatan fitoplankton dan zooplankton dengan salinitas juga relatif tinggi, yaitu 0,7357 dan 0,6169.

Dengan membandingkan gambar (A) dan (B), dapat diketahui bahwa stok teripang di perairan $P$. Panjang Kecil pada bulan Juni dan September (musim timur dan peralihan timur ke barat) dan perairan $P$. Kayu Angin Bira pada bulan Desember (musim barat) kepadatannya relatif tinggi. Kepadatan fitoplankton dan zooplankton yang dipengaruhi oleh salinitas paling tinggi ditemui pada waktu pengamatan bulan Juni (musim timur) di Perairan P. Kayu Angin Bira. Kepadatan stok teripang di perairan $P$. Kayu Angin Bira pada musim tersebut relatif tinggi, yaitu $1.710 \mathrm{ind} /$ hektar.

\section{KESIMPULAN}

1. Di perairan Kepulauan Seribu ditemukan lima belas jenis teripang, sebelas jenis diantaranya dikonsumsi. Dari sebelas jenis yang dikonsumsi, dua jenis bernilai ekonomis tinggi dan sembilan jenis lainnya nilainya rendah sampai sedang. Kepadatan stok berkisar antara 120-2.330 ind/ha. Kepadatan stok relatif tinggi berlangsung pada musim timur sampai musim peralihan timur ke barat, berkisar antara 990-2.330 ind/ha. Pada musim barat kepadatannya mulai menurun, berkisar antara 570-600 ind/ha. Kepadatan stok relatif rendah pada musim peralihan barat ke timur, yaitu 120 ind/ha.

2. Pola penyebaran teripang merata dan tidak ada spesies yang mendominasi.

3. Karakteristik fisika-kimia dan biologi perairan Kepulauan Seribu sesuai dengan habitat teripang, nilai parameternya masih dalam batas optimal untuk pertumbuhan teripang.
4. Ada kecenderungan bahwa kepadatan stok teripang dipengaruhi oleh kedalaman perairan dan kecepatan arus

5. Dalam upaya meningkatkan dan melestarikan populasi sumber daya teripang di perairan Kepulauan Seribu, ada kemungkinan untuk dilakukan usaha pembesaran (budidaya) maupun pengkayaan stok, karena ekosistem perairannya relatif stabil untuk pertumbuhan teripang.

\section{DAFTAR PUSTAKA}

Azkab, H. M. \& M. Hutomo. 1986. Sumber daya Kepulauan Seribu dan peranan stasiun penelitian oseanologi Pulau Pari. Oseana, 11(2): 45 .

Brower, J.E., \& J.H. Zar. 1977. Field and laboratory methods for general ecology. WM. J. Brown Company Publ., Dubuque. lowa.

Direktorat Jenderal Perikanan. 1988, 1989, dan 1995. Statistik ekspor dan impor hasil perikanan. Direktorat Jenderal Perikanan. Departemen Pertanian. Jakarta.

Hartati, S.T., I.S. Wahyuni \& E. Reswati, 2002. Perikanan teripang di perairan Kepulauan Seribu. Jurnal Penelitian Perikanan Laut. 8(4): 55--64.

Krebs, C. 1989. Ecological methodology. Harper and Rowe. New York.

Magurran, Anne E. 1955. Ecological diversity and its measurement. Princeton University Press. United States of America.

Martoyo, J., N. Aji \& T. Winanto. 1996. Budi daya teripang. Penebar Swadaya. Jakarta, $69 \mathrm{pp}$.

Odum, E. P. 1971. Fundamental of ecology $3^{\text {rd }}$ Edition. W. B Sounders Company. Philadelphia.

Sutaman, 1993. Petunjuk praktis budi daya teripang. Penerbit Kanisius Yogjakarta. 68 pp.

Teswara, A. 1995. Perbandingan komposisi jenis-jenis teripang (Holothurioidea) di P. Kayu Angin Bira dan P. Pramuka. Taman Nasional Laut PulauPulau Seribu, Jakarta. Universitas Nasional. Jakarta.

Tuwo, A. \& C. Conand, 1992. Development in bechede-mer production in Indonesia during the last decade. Beche-de-mer Information Bull, 4:2-3.

Tuwo, A. \& M.N.Nessa, 1991. Beberapa aspek biologi teripang ekonomis. Bulletin IImu Kelautan, Torani, 1(1): 1-20. 
